ELORE (ISSN 1456-3010), vol. $13-1 / 2006$.

Julkaisija: Suomen Kansantietouden Tutkijain Seura ry. Taitto: Jukka Talve. [http://cc.joensuu.fi/ loristi/1_06/fls1_06.pdf]

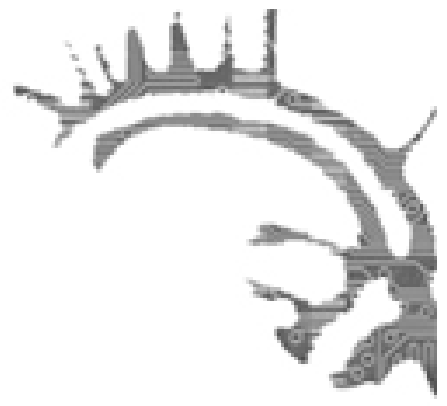

\title{
REVIEW:
}

\section{FinNish Oral History Network}

\author{
Outi Fingerroos, Simo Laakkonen, Kirsti Salmi-Niklander
}

\section{The BEgINNING}

Although the academic discussion on oral history in Finland started in the 1980s, the collection of oral history materials had already commenced in the 1960s. The emergence of studies in oral history has been closely linked to the archives and public sector research projects (see Kalela 1986; Ukkonen 2000). The archives of the Labour Movement established oral history collections to complete official documents. The Workers' Oral History Commission in the Workers' Archives began to organize a collection of thematic memoirs and autobiographies in 1960. In People's Archives a remarkable collection of interviews and written memoirs of political prisoners was produced during the 1980s.

An important event in the Finnish oral history research was the history project of the Finnish Paper Workers' Union organized by Jorma Kalela in 1979-1986. In this project the local labour unions studied their own history in interaction with academically trained historians. (See Kalela 1982a;1982b; 1983a; 1983b; 1983c; 1984a; 1984b; 1984c; 1986.) The purpose of the project was that "people would write their own history themselves". New trends spread quickly to include comprehensively in their scope the so-called history from below, that is, the history of workers, women, children and other groups of people overlooked by conventional history research. At the same time folklorists had also begun to take notice of the possibilities new oral history sources were opening up. (Knuuttila 1983; 1984; Lehtipuro 1982; Peltonen 1984.)

In the Folklore Archives of Finnish Literature Society the collecting competition on the memories of the Civil War (1965-1969) was an important turning point, since it was focused on oral history rather than traditional folklore genres (Peltonen 1996, 65-71). The collecting competition on the lumberjack tradition (1969) 


\section{Outi Fingerroos, Simo Laakkonen, Kirsti Salmi-Niklander}

was very popular and attracted a vast amount of new writers and interviewers. These collections became material for academic research in the 1990s, when the doctoral theses of Ulla-Maija Peltonen (Punakapinan muistot [Memoirs of the Civil War], 1996) and Jyrki Pöysä (Jätkän synty [The Birth of the Lumberjack], 1997) were published. Ulla-Maija Peltonen's study was a comprehensive analysis of orally transmitted folk history regarding the Civil War. She used the term recollected narratives which includes life histories, memoirs, memorates, rumour and gossip. She was especially interested in the ways how people reacted to, processed, interpreted and survived the arbitrary violence. She has continued her research with a monograph on the remembering and forgetting the Civil War, called "Sites of Memory" [Muistin paikat, 2003]. Jyrki Pöysä, on the other hand, deconstructed the image of the lumberjack by revealing the formation of social categories embedded in(to) historical situations. He studied the materials in the collection as a dialogue and analysed various positions of the interviewees.

A typical feature of the Finnish oral history collections and research is that a large part of these materials are actually in written form as autobiographies or answers to thematic questionnaires and collecting competitions organized by the archives. Many of the researchers specializing in oral history have also worked in the archives at some part of their research career. Collecting competitions have provided large amounts of material which can be processed and analysed faster and more easily than taped interviews. The analysis of written memoirs and interviews requires different methodology, but the researchers of these materials have also found many common interests in the theoretical field of oral history. The very first oral history seminar in Finland was organized by the Finnish Literature Society Folklore Archive in 1984. The speakers included, among others, Seppo Knuuttila, Outi Lehtipuro and Jorma Kalela. (Peltonen 1984, 38-39.)

\section{ACADEMIC ORAL HISTORY RESEARCH}

During the early 1980s the methodological discussion on oral history research brought together folklorists, ethnologists, anthropologists and sociologists. The dialogue between the archival practices and academic studies in oral history, however, did not start until the 1990s. In the field of folklore the breakthrough of oral history began in the 1990s and is still continuing. In addition to contemporary interview materials scholars began to pay closer attention to the contexts of traditional data. What and how people tell about their own past, to whom and with what purpose they tell about it, as well as how they themselves interpret their narration orally and in writing came to be considered eminent questions. The earlier question "what do community members tell about themselves?" was appended with a second one: "how do they tell about themselves?" Oral history narratives are partly individual, but they also refer to common collective concepts of, for example, good or bad lifestyles. (Heimo \& Peltonen 2005 [online].) 
During the late 1990s and the first years of the $21^{\text {st }}$ century the methodology of oral history studies has attracted a number of scholars in folklore studies, ethnology and history. In the field of ethnology, Hanna Snellman (1996) has studied the oral history of lumberjacks based on fieldwork and interviews. Hilkka Helsti (2000) has utilised the memoirs collected by the National Board of Antiquities in her study on the conflicts between motherhood and maternity education in Finland. Pirjo Korkiakangas (1996) has analysed the narration in childhood memories.

In the field of Folklore Studies, the reminiscence and the personal experience narrative have become key concepts for many researchers. Taina Ukkonen (2000) has analysed the characteristics of the reminiscence talk in labour movement in Turku and among female metalworkers, and studied the application and realization of the principles of oral history in these projects. Lena Marander-Eklund (2000) from Åbo Akademi has studied the personal experience narratives related to modern childbirth. Tarja Raninen-Siiskonen (1999) has done a case study of reminiscence and narration of the Evacuated Karelians in Finland.

Many researchers have utilised the material produced in collecting competitions, among them Pauliina Latvala's thesis on family history (2005), in which she analysed the narratives pattern in the family history and the different views on agrarian culture represented in these narratives. For some researchers the comparison of different source materials - interviews, archival sources and written memoirs - is an essential part of their methodology. For instance, the theses of Outi Fingerroos (2004) and Kirsti Salmi-Niklander (2004) focused on the first decades of the $20^{\text {th }}$ century. Fingerroos studied the meanings of death rituals in oral tradition from the Karelian Isthmus 1917-1939. She analysed the dialogic relationship of the interviews, written memoirs and other archival materials. Salmi-Niklander used the term "oralliterary local tradition" to include both oral and written texts produced in local communities and focusing on local events and experiences. Her main source materials were hand-written newspapers edited by working-class youth in the industrial community of Karkkila at the beginning of the $20^{\text {th }}$ century. She also analysed the relationship and differences of "personal experience narratives" and "local event narratives".

From Working Hands to Clean and Writing Hands by Saara Tuomaala (2004) is the first doctoral thesis in the field of history based mostly on interview material. It is a study of rural childhood and its formation in relation to modernization in Finland after education was made compulsory in 1921. Saara Tuomaala approaches the modernization of agrarian childhood as a process narrated and experienced on different levels.

At the moment, several doctoral theses dealing with oral history are being conducted in Finnish universities. These theses are closely tied to locality, social conflicts and social relations. 
Outi Fingerroos, Simo Laakkonen, Kirsti Salmi-Niklander

\section{FOHN - Finnish Oral History Network}

A group of Finnish oral historians have formed a network called FOHN - Finnish Oral History Network in the course of the past three years. This network consists of cultural studies scholars and historians from different universities. The activities of the network are international and the aim is to gain visibility. Despite these goals, it is not the aim of the members of FOHN to establish a scientific society. Instead, the society aims to provide inspiring, free-form activities which are as open as possible. The society welcomes all scholars who take an interest in collecting and using oral history sources and materials, or related methodological issues. The network maintains an email mailing list to which it is possible to register by sending contact details to $<$ anne.heimo*utu.fi>.

Before founding the society, the current members had already organized meetings and discussed ideas for a society. The first steps were taken in a meeting of doctoral students at the University of Joensuu in 2002. Later during the same year, a two-day seminar "Oral History - The Challenges of Methodology" was arranged for doctoral students in Helsinki. The keynote speaker of the seminar was an internationally known oral historian Alessandro Portelli (University of Rome, La Sapienza), who also commented the papers presented by students. This seminar was followed by the spring symposium of the doctoral school "Methodological Choices in Oral History" in the School of Cultural Research of the University of Turku in spring 2004. Alessandro Portelli and Vieda Skultans (UK, Bristol) were the keynote speakers of the symposium.

The present issue of Elore is the first common publication by scholars acting in FOHN. There was a demand for a theme issue to be published in English, since the scholars did not share a common language or a publication forum and therefore did not receive information about oral history projects in the neighbouring areas. In addition, the Finnish oral historians are editing a collection called Oral History. Methodological issues (Muistitietohistoria. Metodologisia kysymykesiä), which will be published in 2006. The editorial staff includes Outi Fingerroos, Riina Haanpää, Anne Heimo and Ulla-Maija Peltonen. This collection is aimed as a reader primarily for university students and it will include e.g. a Finnish translation of the classic article by Alessandro Portelli "What Makes Oral History Different?" The authors who represent a variety of disciplines approach the methodological issues of oral history from different perspectives.

\section{THE RAPID INTERNATIONALIZATION OF FOHN}

The scholars of FOHN have collaborated with researchers from Baltic countries, Northern countries and Russia. Close collaboration has resulted in the formation of the Nordic-Baltic Oral History Network. The idea of this network was first discussed in the thirteenth international conference of the International Oral History Associa- 
tion (IOHA) in Rome 23 to 26 June 2004. The conference participants included representatives from Finland, Sweden, Denmark, Estonia, Russia and Latvia. The first meeting was arranged in Riga, Latvia in September 2004.

The network frequently arranges theme seminars on various subjects. Finnish, Estonian and Latvian scholars jointly organized a seminar "War Memoirs in Life Histories" in Tartu in October 2005. Discussions on this theme were continued in Riga in January 2006, in Hamar, Norway in April 2006 and in Helsinki in November 2006. The main organiser and financer has been a Latvian project, i.e. the National Oral History Project.

The Nordic-Baltic Oral History Network has now its own WebCT in the following address: < http://webct.e-uni.ee/public/TUOHaLHRitNBA/index.html>. WebCT is an online portal into which country-specific information of seminars, research and current projects can be added. The WebCT project is coordinated at the University of Tartu.

The next international event arranged by FOHN will take place in Helsinki 15 to 17 November 2006. This symposium called "Memory and Narration" will so far mark the most ambitious effort to be carried out by FOHN. The event is being organised by FOHN and the Finnish Literature Society in cooperation with the Graduate School of Cultural Interpretations and the department of Folklore of the University of Helsinki. The aim is to bring together scholars from a variety of disciplines in Northern Europe to discuss Oral History as well as its methodological and theoretical issues. The programme includes both presentations and thematic sessions.

\section{NeTWORKING}

The Nordic-Baltic network on oral history studies was originally initiated by Mara Zirnite from the Association of Latvian Oral History and Knut Djupedal from Norwegian Emigrant Museum. Their mutual interest was gathering and organising memories of Latvian and Norwegian emigrants. The new general theme for the network has been environmental oral history focusing on coastal regions. In the following we shall briefly describe a few main stages in the development of the NordicBaltic network on history studies.

\section{Towards Nordic-Baltic network}

The prerequisites for expanding the original Norwegian-Latvian network to NordicBaltic oral history network were laid in a three-day conference organised by our Latvian colleagues at the University of Latvia in May 2003. The conference concentrated on the role of oral history in shaping cultural and personal identity. The well-organised conference offered an interesting cross-section of the lively oral history studies, particularly in Latvia and Estonia. 


\section{Outi Fingerroos, Simo Laakkonen, Kirsti Salmi-Niklander}

A follow-up seminar on a smaller scale was arranged the following summer in Riga by the Association of Latvian Oral History arranged by Māra Zirnīte and Baiba Bela-Krūmiņa from the Institute of Philosophy and Sociology, University_of Latvia. This seminar was participated by new researchers from the universities of Dortmund, Joensuu, Tartu, Turku and Helsinki. The research initiative on coastal environmental history was encouraged by a memorable tour in a minibus along the beautiful Latvian coastline, including the Livonian Coast where the last remnants of this small Finno-Ugrian culture may still be seen.

Due to the anniversary marking the end of the Second World War next seminar was dedicated to studies on war and life history. The two-day seminar was organised mainly by Rutt Hindrikus from the Estonian Life Histories Association and held in October 2005 in Tartu. The seminar focused on the impact war can have on life histories and life histories as sources in investigating war. The presentations were a poignant reminder, among other things, of the tragic experiences of the Baltic Countries under German and Soviet occupation and of the value of oral history studies in reconstructing the recent past of these nations.

\section{Migration and oral history}

The most recent meeting of the Nordic-Baltic network took place in Norway. A three-day seminar was arranged in early April 2006 in Hamar, a small town situated north of Oslo. Hamar was specifically chosen because the Norwegian emigrant museum is situated in there. The museum director, Knut Djupedal, has a long history of cooperation with Latvian oral history researchers.

The emigration museum was certainly an appropriate place for arranging a seminar on migration, as about one million Norwegian have emigrated from the country in recent history. The emigrant museum with all of its collections provided interesting and cosy facilities for the seminar that was attended approximately by 30 participants who mainly came from Estonia, Latvia, Finland, Norway and the United States.

The overall level of presentations at the seminar was high because the seminar, entitled as migration and oral history, had a clear focus. Hence the three-day seminar provided a coherent whole for the audience. The presentations focused on two issues, history of migration and methodological questions of oral history that enable fruitful discussions between ethnologists and historians concerning different uses of oral history. The combination of for example literature, archival sources, statistical information and oral history poses a true challenge for researchers.

Most people were accommodated in an old manor house situated outside the city of Hamar amid a beautiful pastoral landscape of Norway. The participants were served excellent breakfasts and dinners in the main building that is today being used as a hotel. On the final day of the seminar Knut Djupedal offered the participants a guided tour of the outdoor facilities of the emigrant museum and of the regional museum with outstanding historical buildings combining medieval and modern Norwegian architecture. 


\section{REFERENCES}

FINGERROOS, OUTI 2004: Haudatut muistot. Rituaalisen kuoleman merkitykeset Kannaksen muistitiedossa. Suomalaisen Kirjallisuuden Seuran Toimituksia 985. Helsinki: Suomalaisen Kirjallisuuden Seura.

HEIMO, ANNE \& PELTONEN, ULLA-MAIJA 2005: Folkloristic Oral History Research in Finland. - Oral history research in the Nordic-Baltic area [online, webCT] <http://webct.e-uni.ee/SCRIPT/TUOHaLHRitNBA/scripts/serve_home> [12.4.2006.]

HELSTI, HILKKA 2000: Kotisynnytysten aikaan. Etnologinen tutkimus äitiyden ja äitiysvalistuksen konflikteista. Suomalaisen kirjallisuuden Seuran toimituksia 785. Helsinki: Suomalaisen Kirjallisuuden Seura.

KALELA, JORMA 1982a: Barfotaforskning i Sverige och Finland. - Meddelande fràn arbetarrörelsens arkiv och bibliotek 21/1: 20-25.

- 1982b: Om betydelsen av att kunna gestalta helheten - och att kunna handla själv. - Meddelande frän arbetarrörelsens arkiv och bibliotek 21(3): 30-31.

— 1983a: At producere sin egen historie. Några synspunkter på arbetarnas egen historieforskning. - Wåhl, Birgitte \& Qviller, Björn (eds.), Usynlig historie. Studier $i$ bistorisk metode XVII. Oslo: Universitetsforlaget, 157-166.

- 1983b: Regionale und lokale Arbeiterbewegung vorwiegend bis zum Zweiten Weltkrieg als Forschungsgegenstand. - Kannonier, Reinhard (ed.), Internationale Tagung der Historiker der Arbeiter-bewegung. 17. Linzer Konferenz 1981. Wien: Europa-verlag, 581-582.

— 1983c: Ihmiset kirjoittavat oman historiansa - Paperiliiton historiahanke. - Tiede \& Edistys 8(2): 25-36.

- 1984a: Minnesforskning, oral history och historierörelsen. - Sociologisk Forskning 3-4/1984: 47-67.

- 1984b: Muistitietotutkimus ja historialiike. - Kotiseutu 75(1): 4-5.

- 1984c: Mitä on kansanomainen historia. Miksi sen pitäisi kehittyä ja mihin sitä tarvitaan? - Kotiseutu 75(4): 179-182.

- 1986: Näkökulmia tulevaisunteen. Paperiliiton historia 1944-1986. Helsinki: Paperiliitto. KNUUTTILA, SEPPO 1983: Kansanperinteen varjokuvia kansallisessa kulttuurissa. - Kotisentu 74(1): 4-6.

- 1984: Mitä sivakkalaiset itsestään kertovat - kansanomaisen historian tutkimuskoe. - Saloheimo, Veijo (ed.), Yhteiskunta kylässä. Tutkimuksia Sivakasta ja Rasinmäestä. Karjalan tutkimuslaitoksen julkaisuja n:o 61. Joensuu: Joensuun Yliopisto.

KORKIAKANGAS, PIRJO 1996: Muistoista rakentuva lapsuus. Agraarinen perintö lapsuuden työnteon ja leikekien muistelussa. Kansatieteellinen Arkisto 42. Helsinki: Suomen Muinaismuistoyhdistys.

LATVALA, PAULIINA 2005: Katse menneisyyteen. Folkloristinen tutkimus suvun muistitiedosta. Suomalaisen Kirjallisuuden Seuran Toimituksia 1024. Helsinki: Suomalaisen Kirjallisuuden Seura. 
LEHTIPURO, OUTI 1982: Historialliset tarinat. - Järvinen, Irma-Riitta \& Knuuttila, Seppo (eds.), Kertomusperinne. Kirjoituksia proosaperinteen lajeista ja tutkimuksesta. Tietolipas 90. Helsinki: Suomalaisen Kirjallisuuden Seura.

MARANDER-EKLUND, LENA 2000: Berättelser om barnafödande. Form, innehäll och betydelse $i$ kvinnors muntliga skildring av födsel. Åbo: Åbo akademis Förlag.

PELTONEN, ULLA-MAIJA 1984: Muistitiedon ongelma. - Kotiseutu 75(1): 38-39.

- 1996: Punakapinan muistot. Tutkimus työväen muistelukerronnan muotoutumisesta vuoden 1918 jälkeen. Suomalaisen Kirjallisuuden Seuran Toimituksia 657. Helsinki: Suomalaisen Kirjallisuuden Seura.

- 2003: Muistin paikat. Vuoden 1918 sisällissodan muistamisesta ja unobtamisesta. Suomalaisen Kirjallisuuden Seuran Toimituksia 894. Helsinki: Suomalaisen Kirjallisuuden Seura.

PÖYSÄ, JYRKI 1997: Jätkän synty. Tutkimus sosiaalisen kategorian muotoutumisesta suomalaisessa kulttunrissa ja itäsuomalaisessa metsätyöperinteessä. Suomalaisen Kirjallisuuden Seuran Toimituksia 669. Helsinki: Suomalaisen Kirjallisuuden Seura.

RANINEN-SIISKONEN, TARJA 1999: Vieraana omalla maalla. Tutkimus karjalaisen siirtoväen muistelukerronnasta. Suomalaisen Kirjallisuuden Seuran Toimituksia 766. Helsinki: Suomalaisen Kirjallisuuden Seura.

SALMI-NIKLANDER, KIRSTI 2004: Itsekasvatusta ja kapinaa. Tutkimus Karkekilan työläisnuorten keskusteluybteisöstä 1910-ja 1920-luvnilla. Suomalaisen Kirjallisuuden Seuran Toimituksia 967. Helsinki: Suomalaisen Kirjallisuuden Seura.

SNELLMAN, HANNA 1996: Tukkilaisen tulo ja lähtö. Kansatieteellinen tutkimus Kemijoen metsä-ja nittotyöstä. Oulu: Pohjoinen.

TUOMAALA, SAARA 2004: Työtätekevistä käsistä pubtaiksi ja kirjoittaviksi. Suomalaisen oppivelvollisuuskoulun ja maalaislasten kobtaaminen 1921-1939. Bibliotheca Historica 89. Helsinki: Suomalaisen Kirjallisuuden Seura.

UKKONEN, TAINA 2000: Menneisyyden tulkinta kertomalla. Muistelupuhe oman historian ja kokemuskertomusten tuottamisprosessina. Suomalaisen Kirjallisuuden Seuran Toimituksia 797. Helsinki: Suomalaisen Kirjallisuuden Seura.

Dr. phil Outi Fingerroos is a Research Fellow (Academy of Finland) and works at the School of Cultural Production and Landscape Studies, University of Turku.

Dr. phil Simo Laakkonen is a researcher of Economic and Social History at the Department of Social Science History, University of Helsinki.

Dr. phil Kirsti Salmi-Niklander is a researcher of Folklore, University of Helsinki. 